\author{
Marquette University \\ e-Publications@Marquette
}

College of Communication Faculty Research

and Publications

Communication, College of

$6-2008$

\title{
The Social Reality of Depression: DTC Advertising of Antidepressants and Perceptions of the Prevalence and Lifetime Risk of Depression
}

Jin Seong Park

University of Florida

Jean M. Grow

Marquette University, jean.grow@mu.edu

Follow this and additional works at: https://epublications.marquette.edu/comm_fac

Part of the Communication Commons

\section{Recommended Citation}

Seong Park, Jin and Grow, Jean M., "The Social Reality of Depression: DTC Advertising of Antidepressants and Perceptions of the Prevalence and Lifetime Risk of Depression" (2008). College of Communication Faculty Research and Publications. 24.

https://epublications.marquette.edu/comm_fac/24 


\title{
The Social Reality of Depression: DTC Advertising of Antidepressants and Perceptions of the Prevalence and Lifetime Risk of Depression
}

\author{
Jin Seong Park \\ University of Florida \\ Gainesville, FL \\ Jean M. Grow \\ Marquette University \\ Milwaukee, WI
}

\begin{abstract}
:
This study is rooted in the research traditions of cultivation theory, construct accessibility, and availability heuristic. Based on a survey with 221 subjects, this study finds that familiarity with direct-to-consumer (DTC) print advertisements for antidepressant brands is associated with inflated perceptions of the prevalence and lifetime risk of depression. The study concludes that DTC advertising potentially has significant effects on perceptions of depression prevalence and risk. Interpersonal experiences with depression coupled with DTC advertising appear to significantly predict individuals' perceived lifetime risk of depression. The study ultimately demonstrates that DTC advertising may play a role in constructing social reality of diseases and medicine. The findings strongly suggest that the social cognitive effects of DTC advertising are far-reaching, impacting
\end{abstract}


NOT THE PUBLISHED VERSION; this is the author's final, peer-reviewed manuscript. The published version may be accessed by following the link in the citation at the bottom of the page.

pharmaceutical marketing strategy as well as presenting issues regarding public health and the business ethics of advertising drugs to consumers.

\section{Introduction}

Throughout the 1990s, direct-to-consumer (DTC) advertising was one of the most rapidly growing categories of advertising (Davis, 2000). The U.S. expenditure on DTC advertising increased from $\$ 25$ million in 1988 (Morgan and Levy, 1998), to $\$ 1.07$ billion in 1996, and to $\$ 2.7$ billion in 2002 (U.S. General Accounting Office, 2003). By 2000 , DTC advertising accounted for $15 \%$ of the total promotional budget in the pharmaceutical industry (Brichacek and Sellers, 2001). As a result, DTC advertising constituted $2.5 \%$ of the total advertising expenditure in the U.S. market in 2000, (NIHCM, 2001) becoming the fourth largest consumer-advertising category (Blankenhorn et al., 2001).

Promoting prescription drugs directly to consumers has caused a nation-wide controversy in the U.S. Opponents of DTC advertising argue that it does not provide fair and balanced information about the health benefits and risks of a drug (Bell et al., 2000; Coney, 2002). They also point out DTC advertising may substantially increase health care costs (Findlay, 2001), and adversely affects the doctor-patient relationship, as doctors increasingly acquiesce to patients' requests for the drugs they see in DTC advertising (Bell et al., 1999; Mintzes et al., 2002). In line with these critical viewpoints, in the race for 2004 Democratic presidential nomination, candidate Howard Dean called for a ban on DTC advertising as an element of his 6-point plan to reduce prescription drug costs. Two other candidates, Richard Gephardt and John Edwards, expressed similar criticisms (Teinowitz, 2003).

In contrast, proponents argue the content of DTC advertising has fair and balanced benefit and risk information and therefore can educate consumers about diseases and treatments (Calfee, 2002). They further argue DTC advertising can increase awareness of, and encourage treatment of, stigmatized and under-diagnosed illnesses such as hypercholesterolemia and clinical depression (Calfee, 2002; Holmer, 2002). Proponents also points out that DTC advertising encourages consumers to search for more information about health conditions and treatments (Allison-Ottey et al., 2003; Perri and

Journal of Business Ethics, Vol. 79, No. 4 (2008): pg. 379-393. DOI. This article is C Springer and permission has been granted for this version to appear in e-Publications@Marquette. Springer does not grant permission for this article to be further copied/distributed or hosted elsewhere without the express permission from Springer. 
Dickson, 1988) as well as encourages compliance (Donohue et al., 2004) and exerts positive influences on the doctor-patient interaction (Holmer, 1999). In fact, when candidate Howard Dean's pledge to ban DTC advertising received media coverage, Dan Jaffe, executive vice president of the Association for National Advertisers, called the candidate's plan "a prescription for disaster" and added, "[DTC] advertising often provides consumers [with] extremely valuable information that can save lives, often avoids serious health problems and in so doing often lowers health costs" (Teinowitz, 2003, p. 1).

Since the "DTC explosion" in the 1990s, researchers have explored how DTC advertising is associated with consumer attitudes, intention and behavior. For example, Sumpradt et al. (2002) find positive attitudes toward DTC advertising predicts willingness to discuss advertised drugs with doctors. Beltramini (2006) further finds consumers' perceived believability and comprehension of information in DTC advertising predict their plan to consult doctors about health issues and request prescriptions for the specific drugs they saw in advertising. When doctors refuse to prescribe the requested drugs, many consumers are dissatisfied and insist on prescriptions for the drugs (Bell et al., 1999; Mehta and Purvis, 2003). In fact, researchers (Herzenstein et al., 2005; Kravitz et al., 2005) find consumers' requests for drugs, based on exposure to DTC advertising, increase the likelihood of doctors' prescribing the drugs. At an industry level, Iizuka and Jin (2005) find the pharmaceutical industry's expenditures on DTC advertising are associated with consumers' increased visits to doctors' offices. Zachry et al. (2002) further reveal the DTC expenditures for antilipemics significantly predicts the number of diagnoses of hyperlipidemia, prescriptions for antilipemics in general, and prescriptions for Zocor. Overall, from a marketing perspective DTC advertising appears to be successful.

Despite a large body of research, the current literature on the effects of DTC advertising on consumers is limited for a number of reasons. The literature is mostly centered around DTC advertising's impact on the way consumers seek health information and interact with doctors to get specific drugs, focusing on variables such as consumers' awareness and attitudes regarding DTC advertising, visits to doctors' offices, requests for specific drugs, etc. These are important variables and deserve attention. However, a body of 
literature from social cognition suggests DTC advertising can have more far-reaching influences on the way consumers perceive the "social reality" of diseases. Elliott (2003), a physician and professor of bioethics, suggests as much. Using the case of Paxil, he argues that "social reality" can be manipulated to the point where new disease categories, such as "social anxiety disorder," are largely constructed by the pharmaceutical industry in an effort to expand drug therapy. Elliott (2003) further argues that many drugs advertised to consumers promote newly constructed diseases, and thus new disease categories rather than promoting public heath.

\section{Purpose of the study}

Considering the minimal research available on the social cognitive effects of DTC advertising, this study focuses on DTC advertising's potential influences on consumers' perception of diseases. Specifically, based on cultivation theory, construct accessibility (Sherman and Corty, 1984) and availability heuristic (Tversky and Kahneman, 1973), we will explore how consumers' familiarity with DTC advertisements for one specific category of drugs, antidepressants, is associated with their perceived social reality of depression. We intend to achieve this purpose by testing how consumers' familiarity with DTC print advertisements for antidepressants, namely Prozac (produced by Elli Lilly), Paxil CR (GlaxoSmithKlein, GSK), Zoloft (Pfizer), Wellbutrin XL (GSK) and Effexor XR (Wyeth), relates to their perceptions of the prevalence and lifetime risk of clinical depression. In addition, we will also explore how consumers' interpersonal experiences with depression, namely awareness of their personally meaningful others' experiences with depression, may be associated with their perceptions.

Of many categories of disease, this study focuses on depression for a number of reasons. First, antidepressants, such as Paxil CR and Zoloft, have been one of the most heavily advertised prescription drug categories in the DTC market (Rosenthal et al., 2002). This may be driven by the fact that depression is the most common form of severe mood disorders (Altshuler et al., 1998; Weiss and Lonnquist, 1997). Second, depression remains a largely under-diagnosed disease category (Holmer, 2002). National Institute of Mental Health (NIMH, 2000) reports, "most people with a depressive illness do not seek 
treatment" (p. 1). In fact, it would be common for patients to experience social stigma related to depression (Elliott, 2003; Holmer, 2002; Kravitz, 2000). Third, symptoms of depression, such as loneliness, feeling of social isolation and worthlessness, and difficulty with thinking (American Psychiatric Association, 1994), suggest DTC antidepressants advertising is targeted toward a potentially vulnerable group of consumers. Hollon (2004) points out special attention is required regarding the effects of DTC advertising targeted toward consumers suffering psychiatric and neurological illnesses, because their decisional capacity may be impaired.

Last, Donohue and Berndt (2004) reveal pharmaceutical companies' expenditures on DTC antidepressant advertising are associated with an overall increase in the number of prescriptions for antidepressants. Apart from an increase in the requests for specific drugs, they call this expansion of a drug category "a treatmentexpanding effect" (Donohue and Berndt, 2004, p. 124). Given that risk perception generally increases intention to seek health information and avoid risk behavior and prevent illnesses (Block and Keller, 1998; Irwin et al., 1996; Raghubir and Menon, 1998; Siegel et al., 1998), we believe that this study, addressing consumers' prevalence and risk perceptions of depression, will add valuable social cognitive insights to the treatment-expanding power of DTC advertising; and thus implications for public health and business ethics as well as marketing strategy.

\section{Theoretical background}

Cultivation is a theory about the cumulative effects of television consumption on viewer conceptions of social reality. Rooted in the assumption that television dominates the "symbolic reality of modern life"(Gerbner, et al., 1980, p. 5), cultivation theorists posit that the amount of television watching is positively related to the degree to which people's beliefs about particular features of social reality mesh with the way they are portrayed on television (Potter, 1993). This occurs because viewers tend to integrate television information into their conceptions of social reality (Potter, 1993).

Cultivation theorists have explored how television watching predicts viewers' perception of the prevalence of crimes and violence

Journal of Business Ethics, Vol. 79, No. 4 (2008): pg. 379-393. DOI. This article is (C Springer and permission has been granted for this version to appear in e-Publications@Marquette. Springer does not grant permission for this article to be further copied/distributed or hosted elsewhere without the express permission from Springer. 
(Gerbner, et al., 1978, 1979, 1980; Hawkins and Pingree, 1980), prostitution, alcoholism, and drug use (Shrum and O'Guinn, 1993), as well as undesirable sexual behaviors such as teenage pregnancy and marital infidelity (Woo and Dominick, 2003). Particularly relevant to this study, a group of researchers have applied the theory to consumer research. For example, O'Guinn and Shrum (1997) reported exposure to soap operas is positively associated with consumers' perceived prevalence of the use of product categories symbolizing affluent lifestyles. The association likely occurs because soap operas frequently depict affluent lifestyles (O'Guinn and Shrum, 1997) and the television world generally over-represents professionals and the upper middle class, while under-representing the low class (Lichter et al., 1994).

The literature on social cognition indicates cultivation theory is applicable for this study. Social cognition research has consistently found people tend to use little information in making social estimates (Taylor and Fiske, 1978; Wyer and Srull, 1989). Researchers (Higgins et al., 1977; Roskos-Ewoldsen and Fazio, 1997; Taylor and Fiske, 1978) propose information, consisting of constructs, most accessible in making social estimates tends to be used most frequently, a process known as construct accessibility. In making social judgments, these judgment-related accessible constructs come to mind as "exemplars" of the judgment domain and influence overall social estimates (Shrum, 2003). Elliott (2003) contends pharmaceutical companies construct depression as widespread and common through DTC advertising. We propose such construction occurs as DTC advertising increasingly disseminates exemplars with which consumers can make social judgments. By means of activating a process of construct accessibility (Sherman and Corty, 1984), DTC advertising may have a role in the social construction of depression.

Further, more accessible information can also influence social estimates through the principle of availability heuristic (Tversky and Kahneman, 1973), which posits the more easily people can retrieve information, such as relevant examples, from their memory regarding a certain feature of social reality, the more prevalent or frequent they perceive the phenomenon to be. The ease of retrieving relevant information becomes a heuristic that tends to inflate individuals' frequency and prevalence estimates of a phenomenon. We expect that accumulated exposure to DTC advertisements for antidepressants will

Journal of Business Ethics, Vol. 79, No. 4 (2008): pg. 379-393. DOI. This article is @ Springer and permission has been granted for this version to appear in e-Publications@Marquette. Springer does not grant permission for this article to be further copied/distributed or hosted elsewhere without the express permission from Springer. 
lead individuals to be more familiar with them, and familiarity will make consumers' memory regarding depression and antidepressants more accessible.

A group of researchers (O'Guinn and Shrum, 1997; Shrum and Bischak, 2001; Shrum and O'Guinn, 1993) propose the principles of construct accessibility and availability heuristic account for the psychological processes leading to cultivation effects. They suggest the media frequently present relevant exemplars of a feature of social reality, making these exemplars highly accessible. Consumers comfortably make social estimates partly under the influence of these exemplars, and the ease of retrieval of the exemplars tends to drive up their social estimates (Shrum and O'Guinn, 1993). Similar to television shows, advertising messages can function as a source of information that can be stored in people's memory and retrieved for social judgments. For example, studies reveal consumers' exposure to advertising can increase the perceived ease of retrieving positive attributes of a product (Menon and Raghubir, 2003) or their own cognitive responses to an advertisement for it (Tybout et al., 2005), influencing evaluations of the product.

This study is based on the assumption that DTC advertising for antidepressant brands can be a source of accessible information that is stored in consumers' memory and influences their estimates of the prevalence and lifetime risk of depression. An (2007) finds consumers' unaided recall of print DTC antidepressant advertisements positively predicts their perceived prevalence of depression. The study did not control for interpersonal experiences with depression, while social cognition researchers (Higgins and King, 1981; Shrum and Bischak, 2001; Wyer and Shrull, 1989) point out various modes of experiences with a social phenomenon have influences on the perceived social reality of the phenomenon. An (2007) also did not test the relationship between recall and consumers' own perceived lifetime risk of depression.

Building on An (2007) and the studies in the past that exhibit a relationship between media exposure and higher prevalence and risk perceptions, we hypothesize that, after controlling for interpersonal experiences with depression, the more familiar consumers are with DTC advertisements for antidepressants, the more prevalent they will

Journal of Business Ethics, Vol. 79, No. 4 (2008): pg. 379-393. DOI. This article is (C Springer and permission has been granted for this version to appear in e-Publications@Marquette. Springer does not grant permission for this article to be further copied/distributed or hosted elsewhere without the express permission from Springer. 
perceive clinical depression to be in the U.S. (H1), and the higher they will perceive their own lifetime risk of depression to be $(\mathrm{H} 2)$. We assert familiarity is a more appropriate independent variable than recall to predict social cognition, because recall requires active and intensive information processing, while social judgments driven by availability heuristic can be formed and retrieved through semi-conscious, automatic information processing (Menon and Raghubir, 2003). In fact, in An's (2007) study, 65\% of survey respondents did not recall any advertised antidepressant brand, and $25 \%$ recalled just one of the five advertised brands. Familiarity can be retrieved and influence judgments in a low-involvement, semiconscious manner (Hawkins and Hoch, 1992).

Mass media are not the only information source to influence consumers' perceived social reality of depression. Individuals are embedded in different life patterns and socio-cultural contexts, which present alternative sources of retrievable information and therefore can influence their perceptions of the prevalence and risk of depression independent of the influences from mass media. Such alternative information sources include memory of personal experiences and interpersonal experiences, such as word-of-mouth (Shrum and Bischak, 2001, p. 187). Higgins and King (1981) and Wyer and Srull (1989) suggest information attained through personal experiences is highly accessible when people think about a real-world prevalence of a phenomenon related to such experiences.

We expect interpersonal experiences with depression, conceptualized as knowing personally meaningful others (e.g. family members, relatives and close friends) who suffer from clinical depression and seek professional help, will also present a source of accessible information when individuals report their perceptions of depression, especially for those who have not experienced clinical depression. Therefore, it is hypothesized that the more interpersonal experiences individuals have with depression, the more prevalent they will perceive clinical depression to be (H3) and the higher they will perceive their own lifetime risk of depression to be (H4). This study does not incorporate the role played by direct, personal experiences with depression, because the overwhelming majority of study subjects have not experienced clinical depression. Subjects who reported

Journal of Business Ethics, Vol. 79, No. 4 (2008): pg. 379-393. DOI. This article is @ Springer and permission has been granted for this version to appear in e-Publications@Marquette. Springer does not grant permission for this article to be further copied/distributed or hosted elsewhere without the express permission from Springer. 
NOT THE PUBLISHED VERSION; this is the author's final, peer-reviewed manuscript. The published version may be accessed by following the link in the citation at the bottom of the page.

personal experiences with clinical depression were deleted from data analysis.

\section{Method}

\section{Subjects and procedure}

A survey was conducted with a convenience sample of 221 undergraduates enrolled in introductory advertising courses at a large state university in the U.S. Of the subjects, $68.2 \%$ were females. Subjects ranged in age from 17 to $27(M=20.01$, SD $=1.29)$. The majority were whites (71.9\%), followed by Hispanics $(17.6 \%)$, African-Americans (4.1\%), and Asian-Americans (3.6\%). Subjects were largely from middle (29.9\%) or upper middle class $(54.8 \%)$ families. Only $2.7 \%$ reported they were from working class families.

Subjects received extra credit for participation. The class curriculum did not include topics that could have sensitized subjects to the purpose of this study. Survey instruments were distributed in class, but subjects completed them in private at home. Though less preferable than a random sample from the general population, undergraduates form a solid sample for this study, because consumer socialization and expressions of social reality begin at early life stages (John, 1999; Singh et al., 2003), and depression is increasingly prevalent among young adults (Kessler et al., 2001). However, homogeneity of the sample might yield results different from those found in the general population. Therefore, one should take caution when interpreting findings of this study.

\section{The instrument}

To help subjects differentiate clinical depression, which is the focus of this study, from short periods of sadness, the cover sheet explicitly stated, "depression is defined in this project as a form of medical illness, or a state of sadness that has reached the point of persistently disrupting a person's social functioning and daily activities." In addition, for comparability of subjects' responses with nation-wide epidemiological data for depression, (Kessler et al., 1994; National Comorbidity Survey, 2003; Regier et al., 1993), the cover

Journal of Business Ethics, Vol. 79, No. 4 (2008): pg. 379-393. DOI. This article is C Springer and permission has been granted for this version to appear in e-Publications@Marquette. Springer does not grant permission for this article to be further copied/distributed or hosted elsewhere without the express permission from Springer. 
sheet further emphasized that we defined "adults" as "American men and women of 18 and over."

Besides the dependent and independent variables, the instrument measured a few control variables, such as socio-economic status (SES), gender and interest in DTC advertising, which likely have external influences on the relationships we hypothesized. For example, SES is reported to be associated with media use patterns (Condry, 1989) and an increased risk of depression (Gilman et al., 2003). SES may also influence consumers' perceptions of social reality (Hawkins and Pingree, 1980; Stroman and Seltzer, 1985). Women's lifetime risk of depression is twice as high as that of men (Kornstein and Wojcik, 2002), which may influence their perceived social reality of depression. At the same time, women's media use patterns differ from men's in a way that can influence their perception of depression. For example, Reader's Digest is a popular vehicle for DTC advertising with its subscription rate being the second highest in the U.S., and its readership is skewed towards women (MediaMark, 2002).

In addition, the assumed causal interpretation for the relationships between familiarity with DTC advertisements and consumers' social reality perceptions is that DTC advertising influences perceptions, rather than the other way around. A viable alternative interpretation will be that those who have inflated perception of depression may be interested in DTC advertising, and then become more familiar with DTC antidepressant advertisements. The design of this study significantly reduces this possibility by controlling the interest for DTC advertising.

However a survey design cannot control all sources of external influences. Therefore, one should be cautious in making causal interpretations for the findings generated by this design.

\section{Measures}

\section{Interest in DTC advertising}

Subjects reported their interest in DTC advertising on a sevenpoint scale ( $1=$ not at all interested, $7=$ extremely interested). On

Journal of Business Ethics, Vol. 79, No. 4 (2008): pg. 379-393. DOI. This article is (C) Springer and permission has been granted for this version to appear in e-Publications@Marquette. Springer does not grant permission for this article to be further copied/distributed or hosted elsewhere without the express permission from Springer. 
NOT THE PUBLISHED VERSION; this is the author's final, peer-reviewed manuscript. The published version may be accessed by following the link in the citation at the bottom of the page.

the average, responses were below the mid-point $(M=2.61, \mathrm{SD}=$ 1.40).

\section{Interpersonal experiences}

Subjects checked "yes," "no," or "don't know" for each of the three items asking if they know of someone among their significant others, namely family members, relatives and friends, who have suffered from depression, sought professional help to deal with it or taken an antidepressant. A total of 132 subjects reported that they knew of their significant others who suffered from depression, followed by 128 subjects reporting they knew of someone who took antidepressants. A total of 99 reported they knew of someone who sought professional help to deal with depression. As the items were internally consistent ( $a=.82)$, they were averaged to create a single index score.

\section{Familiarity with DTC advertisements for antidepressants}

The survey included six print advertisements for five brands of antidepressants, including Prozac, Zoloft, Paxil CR, Wellbutrin XL, and Effxor XR. The advertisements were all retrieved from 1997 to 2005 issues of Reader's Digest. Except for Paxil CR, which was represented by two advertisements, each brand was represented by one advertisement. Two ads were used for Paxil CR because advertisements for the brand exhibited considerable variations in terms of overall themes and execution styles, compared to other brands containing only minor variations. Subjects reported how familiar they were with each of the six print advertisements on a seven-point scale ( $1=$ not at all familiar, $7=$ extremely familiar). The items exhibited sufficient internal consistency $(a=.76)$, with a mean of 2.46 ( $S D=1.09$ ). To minimize the risk of test effects, we measured familiarity after prevalence and risk perceptions were measured.

\section{Perceived lifetime risk of depression}

Subjects reported in percentage the chances that they will suffer from depression at some point during their lifetime. Female subjects on the average perceived their lifetime risk to be $29.09 \%$ (SD = 
27.62 ), while males perceived the risk to be $31.33 \%$ (SD $=33.25$ ). It was notable that the two groups did not significantly differ in their perception, considering that epidemiological studies indicate the risk is 20-25\% for women and approximately 13\% for men (Kessler, 1993, 1994; NCS, 2003). Therefore, male subjects had more inflated perceptions of their lifetime risk of depression compared to women.

\section{Perceived prevalence of depression}

A composite measure of perceived prevalence of depression was constructed by selecting and modifying six social reality measurement items from the cultivation theory literature (O'Guinn and Shrum, 1997; Shapiro, 1991; Shrum, 1996). Subjects reported in percentage their "gut-level" estimates of the probability of the following particular situations occurring in the U.S.

(Q1) In a typical year, what percentage of American adults will suffer from depression?

(Q2) In a typical year, what percentage of American households will have one or two members who suffer from depression?

(Q3) In a typical year, what percentage of people with mental illnesses will be categorized as depressive patients?

(Q4) In a typical year, what percentage of male adults will suffer from depression in the US?

(Q5) In a typical year, what percentage of female adults will suffer from depression in the US?

(Q6) In a typical year, what percentage of Americans will have one or two family members, relatives or close friends who suffer from depression?

The six items exhibited high internal consistency $(a=.86)$, and were averaged to create a single index score. Subjects' overall estimate ranged from 7.17 to 77.50 out of 100 in total $(M=38.01, S D$ $=15.68$ ). On the whole, subjects had inflated perceptions about the prevalence of depression. For example, male subjects reported on the 
average that in a typical year, $28.09 \%(S D=17.31)$ of male adults and $35.56 \%$ (SD $=18.69$ ) of female adults would experience clinical depression in the U.S. Female subjects replied that $26.50 \%$ (SD $=$ $14.04)$ of male adults and $35.52 \%(S D=18.17)$ of female adults would undergo depression in a typical year. It was notable that male and female subjects equally overestimated the prevalence of depression among male and female adults, because epidemiological data indicate that about $9.5 \%$ of adults, $12 \%$ of female adults and $7 \%$ of male adults in the U.S. suffer from clinical depression in any given year (Regier et. al., 1993). A more recent study reveals $6.5 \%$ of adults, $8.5 \%$ of female adults, and $4.7 \%$ of male adults reported that they had experienced depression within the last 12-month period before the survey was conducted (NCS, 2003).

\section{Results}

\section{Zero-order correlations}

As a preliminary analysis, zero-order correlations among all the variables were run. Missing data were accounted for by list-wise deletions. Table I shows that significant correlations were found among some of the variables. Especially, a control variable, interest in DTC advertising, was significantly associated with interpersonal experiences with depression $(r=.17, p<.05)$, familiarity with DTC advertisements for antidepressants $(r=.29, p<.001)$ and perceived lifetime risk of depression ( $r=.16, p<.05)$, suggesting the variable could have had external influences had it been not controlled for. There were no moderate to strong associations among control and independent variables, suggesting the models does not have a multicollinearity problem.

\section{Testing the hypotheses}

\section{Hypotheses $1 \& 3$}

A hierarchical multiple regression model was built to test $\mathrm{H} 1$ \& $\mathrm{H} 3$, with list-wise deletions accounting for missing data. Gender, age, ethnicity and SES were entered as the first step. Because ethnicity was a nominal variable with five response categories, it was recoded into four dummy variables, each representing one ethnic category. Interest

Journal of Business Ethics, Vol. 79, No. 4 (2008): pg. 379-393. DOI. This article is (C) Springer and permission has been granted for this version to appear in e-Publications@Marquette. Springer does not grant permission for this article to be further copied/distributed or hosted elsewhere without the express permission from Springer. 
in DTC advertising was entered as the second step, followed by interpersonal experiences as the third step and familiarity with DTC antidepressant advertisements as the fourth step. The dependent variable was perceived prevalence of depression in the U.S.

H1 predicted that college students' familiarity with DTC advertisements for antidepressant brands would be positively associated with perceived prevalence of depression in the U.S. The results supported this prediction in the complete model $(\beta=.18, p<$ .02) (see Table II). H3 predicted that college students' interpersonal experiences with depression would be positively associated with perceived prevalence. $\mathrm{H} 3$ was not supported. The coefficient for interpersonal experiences was positive but did not reach statistical significance $(\beta=.11, p>.13)$ (see Table II). Familiarity with advertisements explained $2.60 \%$ of the variances in perceived prevalence of depression $[F(1,195)=5.49, p<.02]$.

\section{Hypotheses 2 \& 4}

A hierarchical multiple regression model was built to test $\mathrm{H} 2$ and $\mathrm{H} 4$. The model was the same as the one used to test $\mathrm{H} 1$ and $\mathrm{H} 3$, except that the dependent variable was perceived lifetime risk of depression.

$\mathrm{H} 2$ predicted that familiarity with DTC advertisements for antidepressants would be positively associated with perceived lifetime risk of depression. This hypothesis was supported in the complete model ( $\beta=.20, p<.01$ ) (see Table III). H4 predicted that college students' interpersonal experiences with depression would be positively associated with perceived lifetime depression risk. The results also supported this prediction $(\beta=.19, p<.01$ ) (see Table III), although the relationship became weaker than the zero-order correlation $(r=.23, p<.01)$ it had with perceived depression risk (see Table I). Together, the two independent variables explained $7.30 \%$ of the variances in perceived lifetime depression risk $[F(2,194)$ $=7.95, p<.001]$. 
NOT THE PUBLISHED VERSION; this is the author's final, peer-reviewed manuscript. The published version may be accessed by following the link in the citation at the bottom of the page.

\section{Discussion}

Based on the research traditions of cultivation theory, construct accessibility and availability heuristic, this study finds that familiarity with DTC print advertisements for antidepressant brands are positively associated with perceptions of the prevalence and lifetime risk of depression. Interpersonal experiences with depression, defined as the awareness that their meaningful others have suffered from depression, sought professional help, or taken antidepressant medication, significantly predict perceived lifetime risk, but not perceived prevalence of depression.

These findings suggest significant implications in terms of marketing strategy, public health and the business ethics of pharmaceutical advertising. We begin with the strategic marketing implications. Putsis and Dhar (2001) suggest brand promotions produce expansion of a new product category, in addition to brand switching. This suggests promotions are not necessarily a zero-sum game (Putsis and Dhar, 2001). Donohue and Berndt (2004) find DTC advertising for antidepressants increases the number of prescriptions for antidepressants, implying DTC advertising has potentiality to expand the market of antidepressants. The findings of the current study imply DTC advertising's category expanding effect may occur because consumers become familiar with DTC advertisements for antidepressants, and the subjective judgment of familiarity potentially leads them to perceive depression as more prevalent in the US and estimate their own lifetime depression risk to be higher. Research on health behavior shows consumers' risk assessment of a health problem may produce attitudinal and behavioral changes, such as engaging in preventive and remedial behaviors (Block and Keller, 1998; Irwin et al., 1996; Raghubir and Menon 1998; Siegel et al., 1998), including consultation with doctors. Therefore, changes in risk perception triggered by DTC advertising may drive consumers to visit doctors' offices to discuss depression and/or request antidepressant treatment.

Considering that limited market size is one of the major reasons that the introduction of a new product fails, when launching a new drug category, the findings of this study imply pharmaceutical companies may consider using marketing tools to make consumers more aware of the prevalence and risk of the relevant disease

Journal of Business Ethics, Vol. 79, No. 4 (2008): pg. 379-393. DOI. This article is C Springer and permission has been granted for this version to appear in e-Publications@Marquette. Springer does not grant permission for this article to be further copied/distributed or hosted elsewhere without the express permission from Springer. 
category in addition to showing the drug's competitive advantages. As consumers become gradually more familiar with the disease category, more emphasis may be placed on product differentiation, or points of difference between brands in a drug category. This cycle appears to characterize DTC advertising campaigns for antidepressants, as campaigns for early market leaders, such as Prozac and Zoloft, conveyed the message that clinical depression is common, while campaigns for brands launched at a later stage emphasized points of difference. For example, Paxil CR was positioned as a social anxiety disorder treatment, while Wellbutrin XL was positioned as the first antidepressant without sexual side effects. Unlike Prozac and Zoloft, all DTC advertisements for Effexor XR and Wellbutrin XL feature female models, implying the two brands are targeted at women.

The findings also have implications for public health. If DTC advertising potentially influences consumers' perceptions of the social reality of depression, as the findings suggest, what impact will the phenomenon have on consumer health? To that end, we suggest the following three hypothetical situations to further conceptualize how cultivation effects may have occurred in this study.

Situation 1: Consumers may largely have underrated perceptions about the social reality of depression, and cultivation effects lead them to have more realistic prevalence and risk perceptions.

Situation 2: Consumers may largely have overrated perceptions about the social reality of depression, and cultivation effects lead them to have further inflated prevalence and risk perceptions.

Situation 3: Consumers may have perceptions more or less evenly split around the figures presented by the epidemiological data, and cultivation effects may only occur in a group with underrated or overrated perceptions.

Cultivation effects are a positive social phenomenon in the first situation, whereas the second situation indicates a negative phenomenon. The third presents a more complex picture.

Regarding subjects' perceptions of the prevalence of depression, data for this study generally support the second scenario, because on

Journal of Business Ethics, Vol. 79, No. 4 (2008): pg. 379-393. DOI. This article is (C) Springer and permission has been granted for this version to appear in e-Publications@Marquette. Springer does not grant permission for this article to be further copied/distributed or hosted elsewhere without the express permission from Springer. 
the average subjects reported about 38\% $(S D=18.01)$ of adults experience clinical depression each year, whereas epidemiological studies indicate that about 10\% experience it (Regier et al., 1993). On the other hand, regarding the perceived lifetime risk of depression, male subjects reported that their risk would be $32 \%(S D=33.29$ ), whereas females perceived it to be $29 \%(S D=28.05)$. Epidemiological studies suggest that the lifetime risk of depression is approximately $13 \%$ for men and $20-25 \%$ for women (Kessler, 1993, 1994; NCS, 2003).

Interestingly, females had fairly realistic risk perceptions while males were largely unrealistic. When multiple regressions were conducted separately for men $(n=70)$ and women $(n=151)$, the coefficient for familiarity with antidepressant advertisements was .34 $(r<.013)$ for men and .18 $(r<.049)$ for women. This shows cultivation effects regarding lifetime risk perception occurs more strongly among men, who already have inflated perceptions, than among women. Given that depression has been a largely underdiagnosed and stigmatized disease, leading consumers to have further inflated risk perceptions may have positive behavioral consequences, such as encouraging depressed people to visit a doctor's office and leading consumers to comply better with antidepressant medication (Donohue et al., 2004). However, it may also have negative behavioral influences, such as leading consumers to make unnecessary visits to the doctor's office and therefore driving up health costs (Findlay, 2001). Research may be conducted to further explore the behavioral consequences of the cultivation effects observed in the current study.

The findings of this study also have implications for the business ethics of pharmaceutical advertising. Public criticism is mounting against DTC advertising, as opponents contend that consumers are misled by DTC advertising. At FDA hearings they suggested the possibility of placing a ban or moratorium on DTC advertising. To defend DTC advertising, GSK sent 8,000 sales representatives out to manage the public policy issue in its favor (Thomaselli, 2006). The pharmaceutical industry's professional association, the Pharmaceutical Research Manufacturers of America (PhRMA), has been strong proponents of DTC advertising. To that end, in August 2005, PhRMA introduced codes of conduct aimed at providing advertisers with guideline for DTC advertising (PhRMA, 2005, see Appendix A). 
What are the potential implications of PhRMA's principles for the ethics of pharmaceutical advertising, especially regarding the research findings of this study? The preamble to the principles states that a "strong empirical record demonstrates that DTC communications about prescription medicines serve the public health" by increasing awareness of diseases (PhRMA, 2005). Therefore, PhRMA encourages drug companies to promote disease awareness through DTC advertising (see Principle 9 in Appendix A). However, none of the principles refers to the possibility that becoming familiar with DTC advertising for a disease category may result in leading consumes to have overrated perceptions of the risk of the disease. This deletion may be a potential threat to public health, especially when one considers the research finding that the association between familiarity with DTC antidepressant advertising and perceived risk of depression was stronger among those, mostly consisting of male subjects, who already have unrealistically high risk perceptions of depression.

PhRMA (2005) also emphasizes DTC advertising should be designed to "responsibly educate the consumer about that medicine, and, where appropriate, the condition for which it may be prescribed." Given risk perception's potentiality to produce behavioral consequences (Block and Keller, 1998; Irwin et al., 1996; Raghubir and Menon, 1998; Siegel et al., 1998), PhRMA may consider encouraging drug companies to include in DTC advertising information on the prevalence and risk of developing the relevant disease. Such an initiative will increase the educational value of DTC advertising, with higher potentiality to "responsibly" increase consumers' awareness about diseases and medicine and discourage them from having unrealistic perceptions about their vulnerability to the diseases. We argue the PhRMA guideline will help solidify the business ethics of DTC advertising and gain the public's confidence in the value of the new business practice only if it presents such specific and concrete principles to pharmaceutical companies.

\section{Limitations and further suggestions}

The current study has a number of conceptual and methodological limitations. First, although we alluded to causal interpretations of data driven by the perspectives of cultivation theory and availability heuristic, correlational data cannot establish causality. 
Therefore, the findings and their implications for pharmaceutical marketing strategy, consumer health and business ethics should be interpreted with caution. A further study with an experimental design will generate data that allow solid causal interpretations. Equally important, findings of this study relate specifically to DTC print advertising for antidepressants. Future studies may augment the external validity by incorporating both print and broadcast media, because DTC advertising is frequently conducted through broadcast media (Rosenthal et al., 2002) and consumers' processing of information in electronic media may be different from that in print media. In addition, although this study is framed around an early age group at which individuals form perceptions about diseases, it will be interesting to explore how the theoretical perspectives apply to the general population. It should also be noted that this study is based on a convenience sample. Therefore the data do not provide conclusive evidence for the research findings. Insightful as they are, we suggest researchers replicate the research findings with a nationally representative sample. Last, although cultivation theory does not suggest a causal link between prevalence and risk perceptions, Kalichman and Cain (2005) reveal that prevalence perceptions may increase perceptions of risk. Therefore, one may organize a study to construct and test a model of simultaneous interrelationships among the key concepts discussed in the current project.

\section{Acknowledgements}

- $\quad$ The authors thank the anonymous reviewers for their insightful comments. An early draft of this manuscript was presented at the 2006 annual convention for Association for Education in Journalism and Mass Communication.

\section{Notes}

- Jin Seong Park is a doctoral student at the University of Florida in Gainesville. He earned his MA from Marquette University and BA from Korea University in Seoul, Korea. His research interests include health communication and DTC drug advertising, mood and heuristics in consumer information processing and judgments, and international advertising. 
- Jean M. Grow is an assistant professor at Marquette University. She earned her PhD from University of Wisconsin-Madison and her BFA from the School of Art Institute of Chicago. Her scholarly work focuses on controversial advertising case studies. She has published extensively on Nike women's advertising, and her most recent scholarship focuses on DTC advertising of pharmaceuticals and public service announcements for Hepatitis C. In 2005, she coauthoured a book on creative strategy, Advertising Strategy: Creative Tactics from Outside/In (with T. Altstiel). Prior to joining the academy, she worked in the advertising industry with agencies such as DDB Needham, Foote Cone \& Belding, J. Walter Thompson, and Leo Burnett.

- Jin Seong Park, University of Florida, Gainesville, 32608, U.S.A. E-mail: parquette74@hotmail.com

- Jean M. Grow, Marquette University, 53201-1881, Milwaukee, U.S.A.

\section{References}

1. Allison-Ottey, S., K. Ruffin, K. Allison and C. C. Ottey: 2003, 'Assessing the Impact of Direct-to-Consumer Advertisements on the AA Patient: A Multitude Survey of Patients During the Office Visit', Journal of the National Medical Association 95(2), 120131.

2. Altshuler, L. L., V. Hendrick and V. K. Burt: 1998, 'Mood Disorders', in L. A. Wallis (ed.), Textbook of Women's Health (LippincottRaven Publishers, Philadelphia, PA).

3. An, S.: 2007, 'Antidepressant Direct-to-Consumer Advertising and Social Perception on the Prevalence of Depression: Application of the Availability Heuristic', Health Communication (forthcoming).

4. American Psychiatric Association: 1994, Diagnostic and Statistical Manual of Mental Disorders IV (American Psychiatric Association, Washington, D.C).

Journal of Business Ethics, Vol. 79, No. 4 (2008): pg. 379-393. DOI. This article is (C) Springer and permission has been granted for this version to appear in e-Publications@Marquette. Springer does not grant permission for this article to be further copied/distributed or hosted elsewhere without the express permission from Springer. 
5. Bell, R. A., R. L. Kravitz and M. S Wilkes: 1999, 'AdvertisementInduced Prescription Drug Requests: Patients' Anticipated Reactions to a Physician Who Refuses', The Journal of Family Practice 48(6), 446-452.

6. Bell, R. A., M. S. Wilkes and R. L. Kravitz: 2000, 'The Educational Value of Consumer-Targeted Prescription Drug Print Advertising', The Journal of Family Practice 49(12), 1092-1098.

7. Beltramini,R. F.: 2006, 'Consumer Believability of Information in Direct-to-Consumer (DTC) Advertising of Prescription Drugs', Journal of Business Ethics 63, 333-343.

8. Blankenhorn, K., N. Duckwitz and M. Kerr: 2001, 'Power to the People', Medical Marketing \& Media 36(8), 66-70.

9. Block, L. G. and P. A. Keller: 1998, 'Beyond Protection Motivation: An Investigative Theory of Health Appeals', Journal of Applied Social Psychology 28(17), 1584-1608.

10. Brichacek, A. and L. J. Sellers: 2001, 'Flexing Their Budgets: Big Pharma Spend Trends', Pharmaceutical Executive. http://www.pharmaportal.com/articles/pe/pe0901_sellers.pdf

11. Calfee, J. E.: 2002, 'Public Policy Issues in Direct-to-Consumer Advertising of Prescription Drugs', Journal of Public Policy \& Marketing 21(2), 174-193.

12. Condry, J. C.: 1989, The Psychology of Television (Lawrence Erlbaum, Hillsdale, NJ).

13. Coney, S.: 2002, 'Direct-to-Consumer Advertising of Prescription Pharmaceuticals: A Consumer Perspective From New Zealand', Journal of Public Policy and Marketing 22(2), 213-223.

14. Davis, J. J.: 2000, 'Riskier Than We Think? The Relationship Between Risk Statement Completeness and Perceptions of Direct-to-Consumer Advertised Prescription Drugs', Journal of Health Communication 5, 349-369.

Journal of Business Ethics, Vol. 79, No. 4 (2008): pg. 379-393. DOI. This article is (C) Springer and permission has been granted for this version to appear in e-Publications@Marquette. Springer does not grant permission for this article to be further copied/distributed or hosted elsewhere without the express permission from Springer. 
15. Donohue, J. M. and E. R. Berndt: 2004, 'Effects of Direct-toConsumer Advertising on Medication Choice: The Case of AntiDepressants', Journal of Public Policy \& Marketing 23(2), 115127.

16. Donohue, J. M., E. R. Berndt, M. Rosenthal, A. M. Epstein and R.G.Frank:2004, 'Effects of Pharmaceutical Promotion on Adherence to the Treatment Guidelines for Depression', Medical Care 42(12), 1176-1185.

17. Elliott, C.: 2003, Better than Well: American Medicine Meets the American Dream (WW. Norton, New York).

18. Findlay, S. D.: 2001, 'Direct-to-Consumer Promotion of Prescription Drugs: Economic Implications for Patients, Payers, and Providers', PharmacoEconomics 19(2),109-119.

19. Gerbner, G., L. Gross, M. Jackson-Beeck, S. Jeffries-Fox and N. Signorielli: 1978, 'Violence Profile no. 9', Journal of Communication 28, 176-207.

20. Gerbner, G., L. Gross, M. Morgan and N. Signorielli: 1980, 'The "Mainstreaming" of America: Violence Profile no. 11', Journal of Communication 30, 10-29.

21. Gerbner, G., L. Gross, N. Signorielli, M. Morgan and M. JacksonBeeck: 1979, 'The Demonstration of Power: Violence Profile no. 10', Journal of Communication 29, 177-196.

22. Gilman, S. E., I. Kawachi, G. M. Fitzmaurice and S. L. Buka: 2003, 'Socio-Economic Status, Family Disruption and Residential Stability in Childhood: Relation to Onset, Recurrence and Remission of Major Depression', Psychological Medicine 33(8), 1341-1355.

23. Hawkins, R. P. and S. Pingree: 1980, 'Some Processes in the Cultivation Effect', Communication Research 7, 193-226.

Journal of Business Ethics, Vol. 79, No. 4 (2008): pg. 379-393. DOI. This article is (C) Springer and permission has been granted for this version to appear in e-Publications@Marquette. Springer does not grant permission for this article to be further copied/distributed or hosted elsewhere without the express permission from Springer. 
24. Hawkins, S. A. and S. J Hoch: 1992, 'Low-Involvement Learning: Memory Without Evaluation', Journal of Consumer Research 19, 212-225.

25. Herzenstein, M., S. Misra and S. S. Posavac: 2005, 'How Consumers' Attitudes Toward Direct-to-Consumer Advertising of Prescription Drugs Influence ad Effectiveness, and Consumer and Physician Behavior', Marketing Letters 15(4), 201-212.

26. Higgins, E. T. and G. King: 1981, 'Accessibility and Applicability: Some "Activation Rules" Influencing Judgement', Journal of Experimental Social Psychology 31, 218-243.

27. Higgins, E. T., W. S. Rholes and C. R. Jones: 1977, 'Category Accessibility and Impression Formation', Journal of Experimental Social Psychology 13, 141-154.

28. Holmer, A. F.: 1999, 'Direct-to-Consumer Prescription Drug Advertising Builds Bridges Between Patients and Physicians', Journal of American Medical Association 281(4), 380-382.

29. Holmer, A. F.: 2002, 'Direct-to-Consumer Advertising-Strengthening our Health Care System', New England Journal of Medicine 346, 526-528.

30. Hollon, M. F: 2004, 'Direct-to-Consumer Marketing of Prescription Drugs: A Current Perspective for Neurologists and Psychiatrists', CNS Drugs 18(2), 69-77.

31. Iizuka, T. and G. Z. Jin: 2005, 'The Effect of Prescription Drug Advertising on Doctor Visits', Journal of Economics \& Management Strategy 14(3), 701-727.

32. Irwin, K. L., R. O. Valdiserri and S. D. Holmberg: 1996, 'The Acceptability of Voluntary HIV Antibody Testing in the United States: A Decade of Lessons Learned', AIDS 10(14), 17071717.

Journal of Business Ethics, Vol. 79, No. 4 (2008): pg. 379-393. DOI. This article is C Springer and permission has been granted for this version to appear in e-Publications@Marquette. Springer does not grant permission for this article to be further copied/distributed or hosted elsewhere without the express permission from Springer. 
33. John, D. R.: 1999, 'Consumer Socialization of Children: A Retrospective Look at Twenty-Five Years of Research', Journal of Consumer Research 26, 183-213.

34. Kalichman, S. C. and D. Cain: 2005, 'Perceptions of Local HIV/AIDS Prevalence and Risks for HIV/AIDS and Other Sexually Transmitted Infections: Preliminary Study of Intuitive Epidemiology', Annals of Behavioral Medicine 29(2), 100-105.

35. Kessler, R. C., S. Avenevoli and K. R. Merikangas: 2001, 'Mood Disorder in Children and Adolescents: An Epidemiologic Perspective', Biological Psychiatry 49, 1002-1014.

36. Kessler, R. C., K. A. McGonagle, M. Swartz, D. G. Blazer and C. B. Nelson: 1993, 'Sex and Depression in the National Comorbidity Survey I: Lifetime Prevalence, Chronicity and Recurrence', Journal of Affective Disorders 29, 85-96.

37. Kessler, R. C., K. A. McGonagle and S. Zhao: 1994, 'Lifetime and 12-month Prevalence of DSM-III Psychiatric Disorders in the United States: Results from the National Comorbidity Study', Archives of General Psychiatry 51, 8-19.

38. Kornstein, S. G. and B. A. Wojcik: 2002, 'Depression', in S. G. Kornstein and A. H. Clayton (eds.), Women's Mental Health: A Comprehensive Textbook (Guilford Press, New York), pp. 147165.

39. Kravitz, R. L.: 2000, 'Direct-to-Consumer Advertising of Prescription Drugs', Western Journal of Medicine 173, 221-222.

40. Kravitz, R. L., R. M. Epstein, M. D. Feldman, C. E. Franz, R. Azari, M. S. Wilkes, L. Hinton and P. Franks: 2005, 'Influence of Patients' Requests for Direct-to-Consumer Advertised Antidepressants: A Randomized Controlled Trial', Journal of the American Medical Association 293(16), 1995-2002.

41. Lichter, S. R., L. S. Lichter and S. Rothman: 1994, Prime Time: How TV Portrays American Culture (Regnery, Washington, DC).

Journal of Business Ethics, Vol. 79, No. 4 (2008): pg. 379-393. DOI. This article is (C) Springer and permission has been granted for this version to appear in e-Publications@Marquette. Springer does not grant permission for this article to be further copied/distributed or hosted elsewhere without the express permission from Springer. 
NOT THE PUBLISHED VERSION; this is the author's final, peer-reviewed manuscript. The published version may be accessed by following the link in the citation at the bottom of the page.

42. Mediamark 2002

http://www.marquette.edu/library/research/descriptions/media mark.html Mehta, A. and S. Purvis: 2003, 'Consumer Responses to Print Prescription Drug Advertising', Journal of Advertising Research 43(2), 194-206.

43. Menon, G. and P. Raghubir: 2003, 'Ease-of-Retrieval as an Automatic Input in Judgments: A Mere-Accessibility Framework', Journal of Consumer Research 30, 230-243.

44. Mintzes, B., M. L. Barer, R. L. Kravitz, A. Kazanjian, K. Bassett, J. Lexchin, R. G. Evans, R. Pan and S. A. Marion: 2002, 'Influence of Direct-to-Consumer Pharmaceutical Advertising and Patients' Requests on Prescribing Decisions: Two Site Cross-Sectional Survey', British Medical Journal 324(7332), 278-279.

45. Morgan, C. and D. Levy: 1998, 'To Their Health', Brandweek 39, 3033.

46. National Comorbidity Survey (NCA): 2003, 'Lifetime Prevalence of DSM-IV/WMH-CIDI Disorders by Sex and Cohort', http://www.hcp.med.harvard.edu/ncs/ftpdir/table_ncsr_by_gen der_and_age.pdf (Accessed in January, 2007)

47. National Institute for Health Care Management Research and Education Foundation (NIHCM): 2001, 'Prescription Drugs and Mass Media Advertising 2000', www.nihcm.org (Accessed in November, 2006).

48. National Institute of Mental Health (NIMH): 2000, Depression, http://www.nimh.nih.gov/publicat/nimhdepression.pdf (Accessed in November, 2006).

49. O'Guinn, T. C. and L. J. Shrum: 1997, 'The Role of Television in the Construction of Consumer Reality', Journal of Consumer Research 23, 278-294.

50. Perri, M. and W. M. Dickson: 1988, 'Consumer Reaction to a Directto-Consumer Prescription Drug Advertising Campaign', Journal of Health Care Marketing 8(2), 66-69.

Journal of Business Ethics, Vol. 79, No. 4 (2008): pg. 379-393. DOI. This article is (C) Springer and permission has been granted for this version to appear in e-Publications@Marquette. Springer does not grant permission for this article to be further copied/distributed or hosted elsewhere without the express permission from Springer. 
51. Potter, W. J.: 1993, 'Cultivation Theory and Research: A Conceptual Review', Human Communication Research 19(4), 564-601.

52. Putsis, W. P. and R. Dhar: 2001, 'An Empirical Analysis of the Determinants of Category Expenditure', Journal of Business Research 52(3), 277-291.

53. Pharmaceutical Research Manufacturers of America (PhRMA): 2005, 'PhRMA Guiding Principles: Direct to Consumer Advertisements About Prescription Medicines', http://www.phrma.org/files/DTCGuidingprinciples.pdf (Accessed in January, 2007)

54. Raghubir, P. and G. Menon: 1998, 'AIDS and Me, Never the Twain Shall Meet: The Effects of Information Accessibility on Judgments of Risk and Advertising Effectiveness', Journal of Consumer Research 25, 52-63.

55. Regier, D. A., W. E. Narrow, D. S. Rae, R. W. Manderscheid, B. Z. Locke and F. K. Goodwin: 1993, 'Epidemiologic Catchment Area Prospective 1-Year Prevalence Rates of Disorders and Services', Archives of General Psychiatry 50(2), 85-94.

56. Rosenthal, M. B., E. R. Berndt, J. M. Donohue, R. G. Frank and A. M. Epstein: 2002, 'Promotion of Prescription Drugs to Consumers', New England Journal of Medicine 346(7), 498-505.

57. Roskos-Ewoldsen, D. R. and R. H. Fazio: 1997, 'The Role of Belief Accessibility in Attitude Formation', The Southern Communication Journal 62, 107-116.

58. Shapiro, M. A.: 1991, 'Memory and Decision Process in the Construction of Social Reality', Communication Research 18, 324.

59. Sherman, S. J. and E. Corty: 1984, 'Cognitive Heuristics', in R. S. Wyer and T. K. Srull (eds.), Handbook of Social Cognition 1 (Lawrence Erlbaum, Hillsdale, NJ), pp. 189-286.

Journal of Business Ethics, Vol. 79, No. 4 (2008): pg. 379-393. DOI. This article is (C) Springer and permission has been granted for this version to appear in e-Publications@Marquette. Springer does not grant permission for this article to be further copied/distributed or hosted elsewhere without the express permission from Springer. 
NOT THE PUBLISHED VERSION; this is the author's final, peer-reviewed manuscript. The published version may be accessed by following the link in the citation at the bottom of the page.

60. Shrum, L. J.: 1996, 'Psychological Processes Underlying Cultivation Effects-Further Tests of Construct Accessibility', Human Communication Research 22, 482-509.

61. Shrum, L. J.: 2003, 'Media Exposure and Exemplar Accessibility', Media Psychology 5(3), 255-282.

62. Shrum, L. J. and V. D. Bischak: 2001, 'Mainstreaming, Resonance, and Impersonal Impact: Testing Moderators of the Cultivation Effect for Estimates of Crime Risk', Human Communication Research 27(2), 187-215.

63. Shrum, L. J. and T. C. O'Guinn: 1993, 'Processes and Effects in the Construction of Social Reality: Construct Accessibility as an Explanatory Variable', Communication Research 20(3), 436471.

64. Siegal, K., V. H. Raveis and E. Gorey: 1998, 'Barriers and Pathways to Testing Among HIV-Infected Women', AIDS Education and Prevention 10(2), 114-127.

65. Singh, N., I. W. Kwon and A. Pereira: 2003, 'Cross-cultural Consumer Socialization: An Exploratory Study of Socialization Influences Across Three Ethnic Groups', Psychology \& Marketing 20(10), 867-881.

66. Stroman, C. A. and R. Seltzer: 1985, 'Media Use and Perceptions of Crime', Journalism Quarterly 62, 340-345.

67. Sumpradit, N., S. W. Fors and L. McCormick: 2002, 'Consumers' Attitudes and Behavior-Toward Prescription Drug Advertising', American Journal of Health Behavior 26(1), 68-75.

68. Taylor, S. E. and S. T. Fiske: 1978, 'Salience, Attention, and Attribution: Top of the Head Phenomenon', in L. Berkowitz (ed.), Advances in Experimental Social Psychology 3 (Academic Press, New York).

Journal of Business Ethics, Vol. 79, No. 4 (2008): pg. 379-393. DOI. This article is C Springer and permission has been granted for this version to appear in e-Publications@Marquette. Springer does not grant permission for this article to be further copied/distributed or hosted elsewhere without the express permission from Springer. 
69. Teinowitz, I.: 2003, 'DTC Ads Become Issue in Race for Democratic Nomination', Advertising Age 74(42), p. 8.

70. Thomaselli, R.: 2006, 'Selling Drugs: Glaxo's Crafty Plan', Advertising Age 77(8), 1-21.

71. Tversky, A. and D. Kahneman: 1973, 'Availability: A Heuristic for Judging Frequency and Probability', Cognitive Psychology 5, 207-232.

72. Tybout, A. M., B. Sternthal, P. Malaviya, G. A. Bakamitsos and S. Park: 2005, 'Information Accessibility as a Moderator of Judgments: The Role of Content Versus Retrieval Ease', Journal of Consumer Research 32, 76-85.

73. U.S. General Accounting Office: 2003, Prescription Drugs: FDA Oversight of Direct-to-Consumer Drug Advertising has Limitations (U.S. General Accounting Office, Washington, DC).

74. Weiss, G. L. and L. E. Lonnquist: 1997, The Sociology of Health, Healing, and IIlness (Prentice-Hall Inc, Upper Saddle River, NJ).

75. Woo, H. J. and J. R. Dominick: 2003, 'Acculturation, Cultivation, and Daytime TV Talk Shows', Journalism and Mass Communication Quarterly 80(1), 109-127.

76. Wyer, R. S. and T. K. Srull: 1989, Memory and Cognition in Its Social Context (Lawrence Erlbaum, Hillside, NJ).

77. Zachry, W. M., M. D. Shepherd, M. J. Hinich, J. P. Wilson, C. M. Brown and K. A. Lawson: 2002, 'Relationship Between Direct-toConsumer Advertising and Physician Diagnosing and Prescribing', American Journal of Health-System Pharmacy 59, $42-49$.

Journal of Business Ethics, Vol. 79, No. 4 (2008): pg. 379-393. DOI. This article is C Springer and permission has been granted for this version to appear in e-Publications@Marquette. Springer does not grant permission for this article to be further copied/distributed or hosted elsewhere without the express permission from Springer. 
NOT THE PUBLISHED VERSION; this is the author's final, peer-reviewed manuscript. The published version may be accessed by following the link in the citation at the bottom of the page.

\section{Appendix}

Table I Zero-order correlations

$* p<.05$ (2-tailed), **p $<.01$ (2-tailed).

\begin{tabular}{lcccccccccc}
\hline Variable & 1 & 2 & 3 & 4 & 5 & 6 & 7 & 8 \\
\hline 1. Gender & - & $-.32^{\star \star}$ & .03 & .08 & .07 & .16 & -.02 & -.05 \\
2. Age & & - & .02 & .10 & $.14 \star$ & -.04 & -.01 & .10 \\
3. SES & & & - & -.03 & $-.16^{\star}$ & -.11 & -.03 & -.08 \\
4. Interpersonal experiences with depression & & & & - & $.17 \star$ & $.16^{\star}$ & $.15^{\star}$ & $.23^{\star \star}$ \\
5. Interest in DTC advertising & & & & & - & $.29 \star \star$ & .02 & $.16^{\star}$ \\
6. Familiarity with DTC antidepressant advertisements & & & & & & - & $.18^{\star}$ & $.27^{\star \star}$ \\
7. Perceived prevalence of depression & & & & & & & - & $.43^{\star \star}$ \\
8. Perceived risk of depression & & & & & & & & - \\
\hline
\end{tabular}

Table II Summary of hierarchical regression

\begin{tabular}{|c|c|c|c|c|c|}
\hline \multirow[t]{2}{*}{ Dependent variable } & \multirow[t]{2}{*}{ Predictor variables } & \multicolumn{4}{|c|}{ Perceived prevalence of depression in the US } \\
\hline & & Zero-order $r$ & $\beta$ & Block $\Delta R^{2}$ & Block $\Delta F$ \\
\hline \multicolumn{2}{|l|}{ Step 1: } & & & .020 & 61 \\
\hline \multicolumn{2}{|l|}{ Gender } & -.02 & -.04 & & \\
\hline \multicolumn{2}{|l|}{ Age } & -.01 & -.01 & & \\
\hline \multicolumn{2}{|l|}{ Income } & -.03 & -.03 & & \\
\hline \multicolumn{2}{|c|}{ Ethnicity (whites, Hispanics, African-Americans, Asians Americans) } & $(.28, .34, .11$ & $.09)$ & & \\
\hline \multicolumn{2}{|c|}{ Step 2: } & & & .001 & .01 \\
\hline \multicolumn{2}{|c|}{ Interest in DTC advertising } & -.02 & -.08 & & \\
\hline \multicolumn{2}{|l|}{ Step 3: } & & & .013 & 2.57 \\
\hline \multicolumn{2}{|c|}{ Interpersonal experiences with depression } & $.15^{\star}$ & .11 & & \\
\hline \multicolumn{2}{|c|}{ Step 4: } & & & $.026^{\star}$ & $5.49 \star$ \\
\hline \multicolumn{2}{|c|}{ Familiarity with antidepressant advertisements } & $.18^{\star}$ & $.18^{\star}$ & & \\
\hline \multicolumn{2}{|c|}{$\star_{p}<.05$ (2-tailed) } & \multicolumn{4}{|c|}{$R^{2}=.060 \mathrm{~F}(10,180)=1.26$} \\
\hline
\end{tabular}

Journal of Business Ethics, Vol. 79, No. 4 (2008): pg. 379-393. DOI. This article is (C Springer and permission has been granted for this version to appear in e-Publications@Marquette. Springer does not grant permission for this article to be further copied/distributed or hosted elsewhere without the express permission from Springer. 
NOT THE PUBLISHED VERSION; this is the author's final, peer-reviewed manuscript. The published version may be accessed by following the link in the citation at the bottom of the page.

Table III Summary of hierarchical regression

\begin{tabular}{|c|c|c|c|c|}
\hline \multirow[t]{2}{*}{ Dependent variable } & \multicolumn{4}{|c|}{ Perceived lifetime risk of depression } \\
\hline & Zero-order $r$ & $\beta$ & Block $\Delta R^{2}$ & Block $\Delta F$ \\
\hline Step 1: & & & .026 & .76 \\
\hline Gender & -.05 & -.06 & & \\
\hline Age & .10 & .08 & & \\
\hline Income & -.08 & -.03 & & \\
\hline Ethnicity (whites, Hispanics, African-Americans, Asians Americans) & $(.32, .35, .23, .12)$ & & & \\
\hline Step 2: & & & .0014 & 2.03 \\
\hline Interest in DTC advertising & $.16^{\star}$ & -.04 & & \\
\hline Step 3: & & & $.037 \star \star$ & $7.83 \star \star$ \\
\hline Interpersonal experiences with depression & $.23 \star \star$ & $.19 \star \star$ & & \\
\hline Step 4: & & & $.036^{\star \star}$ & $7.80 \star \star$ \\
\hline Familiarity with antidepressant advertisements & $.27 \star \star$ & $.20 \star \star$ & & \\
\hline$\star_{p}<.05$ (2-tailed), $\star_{p} p<.01$ (2-tailed) & $R^{2}=.109, \mathrm{~F}(10,179$ & 79) $=2$ & $38^{\star \star}$ & \\
\hline
\end{tabular}

\section{Appendix A}

\section{PhRMA's guiding principles for direct-to-consumer advertising}

To express the commitment of PhRMA members to deliver DTC communications that serve as valuable contributors to public health, PhRMA has established the following voluntary guiding principles.

Principle 1.

These Principles are premised on the recognition that DTC advertising of prescription medicines can benefit the public health by increasing awareness about diseases, educating patients about treatment options, motivating patients to contact their physicians and engage in a dialogue about health concerns, increasing the likelihood that patients will receive appropriate care for conditions that are frequently under-diagnosed and under-treated, and encouraging compliance with prescription drug treatment regimens.

\section{Principle 2.}

In accordance with FDA regulations, all DTC information should be accurate and not misleading, should make claims only when supported by substantial evidence, should reflect balance between risks and benefits, and should be consistent with FDA approved labeling.

Journal of Business Ethics, Vol. 79, No. 4 (2008): pg. 379-393. DOI. This article is (C) Springer and permission has been granted for this version to appear in e-Publications@Marquette. Springer does not grant permission for this article to be further copied/distributed or hosted elsewhere without the express permission from Springer. 
NOT THE PUBLISHED VERSION; this is the author's final, peer-reviewed manuscript. The published version may be accessed by following the link in the citation at the bottom of the page.

\section{Principle 3.}

DTC television and print advertising which is designed to market a prescription drug should also be designed to responsibly educate the consumer about that medicine and, where appropriate, the condition for which it may be prescribed.

\section{Principle 4.}

DTC television and print advertising of prescription drugs should clearly indicate that the medicine is a prescription drug to distinguish such advertising from other advertising for nonprescription products.

Principle 5.

DTC television and print advertising should foster responsible communications between patients and health care professionals to help patients achieve better health and a more complete appreciation of both the health benefits and the known risks associated with the medicine being advertised.

\section{Principle 6.}

In order to foster responsible communication between patients and health care professionals, companies should spend an appropriate amount of time to educate health professionals about a new medicine or a new therapeutic indication before commencing the first DTC advertising campaign. In determining what constitutes an appropriate time, companies should take into account the relative importance of informing patients of the availability of a new medicine, the complexity of the risk-benefit profile of that new medicine and health care professionals' knowledge of the condition being treated. Companies should continue to educate health care professionals as additional valid information about a new medicine is obtained from all reliable sources.

\section{Principle 7.}

Working with the FDA, companies should continue to responsibly alter or discontinue a DTC advertising campaign should new and reliable information indicate a serious previously unknown safety risk.

\section{Principle 8.}

Companies should submit all new DTC television advertisements to the FDA before releasing these advertisements for broadcast.

Journal of Business Ethics, Vol. 79, No. 4 (2008): pg. 379-393. DOI. This article is @ Springer and permission has been granted for this version to appear in e-Publications@Marquette. Springer does not grant permission for this article to be further copied/distributed or hosted elsewhere without the express permission from Springer. 
NOT THE PUBLISHED VERSION; this is the author's final, peer-reviewed manuscript. The published version may be accessed by following the link in the citation at the bottom of the page.

\section{Principle 9.}

DTC television and print advertising should include information about the availability of other options such as diet and lifestyle changes where appropriate for the advertised condition.

Principle 10.

DTC television advertising that identifies a product by name should clearly state the health conditions for which the medicine is approved and the major risks associated with the medicine being advertised.

\section{Principle 11.}

DTC television and print advertising should be designed to achieve a balanced presentation of both the benefits and the risks associated with the advertised prescription medicine. Specifically, risks and safety information in DTC television advertising should be presented in clear, understandable language, without distraction from the content, and in a manner that supports the responsible dialogue between patients and health care professionals.

\section{Principle 12.}

All DTC advertising should respect the seriousness of the health conditions and the medicine being advertised.

\section{Principle 13.}

In terms of content and placement, DTC television and print advertisements should be targeted to avoid audiences that are not age appropriate for the messages involved.

\section{Principle 14.}

Companies are encouraged to promote health and disease awareness as part of their DTC advertising.

Principle 15.

Companies are encouraged to include information in all DTC advertising, where feasible, about help for the uninsured and underinsured.

Journal of Business Ethics, Vol. 79, No. 4 (2008): pg. 379-393. DOI. This article is (C) Springer and permission has been granted for this version to appear in e-Publications@Marquette. Springer does not grant permission for this article to be further copied/distributed or hosted elsewhere without the express permission from Springer. 